\title{
Pemberdayaan Masyarakat Melalui Kelompok Dukungan Sebaya (KDS) pada Orang dengan HIV/AIDS di Kota Ternate Provinsi Maluku Utara Tahun 2020
}

\author{
Nani Supriyatni ${ }^{\bowtie}{ }^{\text {Andiani }}{ }^{1}$ Agustin Rahayu $^{1}$ dan Tutik Lestari $^{1}$ \\ 1 Staf Pengajar Fakultas Ilmu Kesehatan, Universitas Muhammadiyah Maluku Utara. Ternate. Indonesia, \\ Email : naniskm@yahoo.com; andianimahbub@gmail.com; agustinyayu21@gmail.com; tutik198692@gmail.com \\ ${ }^{凶}$ Korespondensi : $\quad$ Nani Supriyatni, Universitas Muhammadiyah Maluku Utara, Ternate, Indonesia, \\ Email : naniskm@yahoo.com
}

\begin{abstract}
ABSTRAK
Program penanggulangan AIDS di Indonesia mempunyai 4 pilar, yaitu pencegahan (prevention); Perawatan Dukungan dan Pengobatan (PDP); mitigasi dampak berupa dukungan psikososio-ekonomi; serta penciptaan lingkungan yang kondusif (creating enabling environment) (Kemenkes, 2015). Komitmen kuat semua unsur di masyarakat bahwa epidemi HIV/AIDS adalah tanggung jawab bersama pemerintah, non-pemerintah dan masyarakat untuk bahu membahu menekan penyebaran HIV/AIDS. Tujuan : Memberikan dukungan secara psikologis pada teman-teman populasi Kunci dan ODHA melalui Kelompok Dukungan Sebaya/Lembaga Kesejahteraan Sosial Maku Dudara. Metode: dilaksanakan dengan Observasi dan wawancara langsung dengan KDS/LKS Makududara dengan Tahapan yaitu Persiapan, Pengkajian, Perencanaan Alternatif Program, Pemformalisasi Rencana Aksi, Pelaksanaan, Evaluasi. Hasil : Setiap pengurus KDS /LKS Maku Dudara memiliki kemampuan sebagai fasilitator dalam memberikan motivasi kepada sesama teman-teman ODHA bahwa mereka membutuhkan dukungan secara psikologis terhadap kondisi kesehatan saat ini (dengan status HIV). Tahap Pelaksanaan Kegiatan Keikutsertaan teman-teman ODHA terlibat di dalam pengurus KDS/LKS Maku Dudara diharapkan mampu menjalankan program kegiatan yang dapat memberi dukungan kepada teman-teman sesama ODHA. Kerjasama antara pengurus KDS/LKS Maku Dudara bersama teman-teman ODHA dengan fasilitas pelayanan kesehatan selama ini berjalan dengan baik. yaitu : Pendampingan dan Penjangkauan Populasi Kunci dan ODHA, Memfasilitasi Akses Layanan Kesehatan, Bincang Bincang Sehat (BBS), Bakti Sosial, Kunjungan Rumah ODHA, Hari AIDS Sedunia (HAS).
\end{abstract}

Keyword: Pemberdayaan, ODHA, LKS, KDS

\section{PENDAHULUAN}

HIV terus menjadi masalah kesehatan masyarakat global yang utama, telah merenggut hampir 33 juta nyawa sejauh ini. Namun, dengan meningkatnya akses ke pencegahan, diagnosis, pengobatan dan perawatan HIV yang efektif, termasuk untuk infeksi oportunistik, infeksi HIV telah menjadi kondisi kesehatan kronis yang dapat dikelola, memungkinkan orang yang hidup dengan HIV untuk menjalani hidup yang panjang dan sehat. Diperkirakan ada 38,0 juta orang yang hidup dengan HIV pada akhir 2019.(WHO, n.d.) Sebagai hasil dari upaya internasional bersama untuk menanggapi HIV, cakupan layanan terus meningkat. Pada 2019, 68\% orang dewasa dan 53\% anak-anak yang hidup dengan HIV secara global menerima terapi antiretroviral (ART) seumur hidup.(WHO, n.d.)

Namun, tidak semua orang dapat mengakses tes, pengobatan dan perawatan HIV. Khususnya, target Super-Fast-Track 2018 untuk mengurangi infeksi HIV pada anak menjadi 40.000 tidak tercapai. Target global untuk tahun 2020 berisiko terlewatkan kecuali tindakan cepat diambil. Karena kesenjangan dalam layanan HIV, 690.000 orang meninggal karena penyebab terkait HIV pada 2019 dan 1,7 juta orang baru terinfeksi. Kelompok populasi kunci dan pasangan seksual mereka menyumbang lebih dari 60\% dari semua infeksi HIV baru secara global pada kelompok usia 15-49 tahun (diperkirakan 62\%) pada tahun 2019.

Menurut Departemen Kesehatan 2015, peningkatan jumlah penderita HIV/AIDS di Indonesia diperkirakan akan terus bertambah, 12-19 juta orang rawan untuk terkena HIV dan diperkirakan ada 
184.929 penduduk yang tertular HIV(Stigma et al., 2017)

Data Kementerian Kesehatan RI sampai dengan Maret 2013 mencatat bahwa jumlah kasus HIV sebanyak 103.759 orang dan kasus AIDS sebanyak 43.347 orang dengan kematian karena AIDS sebanyak 8.288 orang. Persentase infeksi HIV-AIDS tertinggi pada kelompok umur 25- 49 tahun dan faktor risiko tertinggi terjadi pada penularan HIV melalui hubungan seksual berisiko pada heteroseksual. (Kemkes, 2017)

Berbagai upaya telah dilakukan dalam rangka melaksanakan upaya pencegahan dan penanggulangan HIV-AIDS yang lebih terarah, terpadu dan komprehensif untuk mencapai SDGs memiliki tujuan yang lebih universal yaitu untuk mencapai kesehatan dan kesejahteraan bagi semua orang (tujuan ketiga). Dengan tujuan tersebut sudah tidak ada lagi target secara khusus pada satu penyakit tertentu, tetapi lebih mengedepankan kesehatan dan kesejahteraan secara holistik. Dimana untuk mencapai itu berarti segala permasalahan kesehatan dan yang terkait telah dapat ditangani termasuk didalamnya permasalahan HIV dan AIDS.

Program penanggulangan AIDS di Indonesia mempunyai 4 pilar, yaitu pencegahan (prevention); Perawatan, Dukungan, dan Pengobatan (PDP); mitigasi dampak berupa dukungan psikososio-ekonomi; serta penciptaan lingkungan yang kondusif (creating enabling environment) (Kementerian Kesehatan Republik Indonesia, 2015). Komitmen kuat semua unsur di masyarakat bahwa epidemi HIV/AIDS adalah tanggung jawab bersama pemerintah, non-pemerintah dan masyarakat untuk bahu membahu menekan penyebaran HIV/AIDS. KDS/LKS merupakan sutau komunitas yang mempunyai program upaya promotif, preventif, kuratif dan rehabilitatif yang mencakup semua bentuk layanan HIV dan IMS, misalnya kegiatan KIE pengetahuan komprehensif, promosi penggunaan kondom, pengendalian faktor risiko dan layanan Konseling Tes HIV (KTH). Sedangkan layanan yang berkesinambungan adalah pemberian layanan HIV secara paripurna sejak dari rumah/komunitas sampai ke fasilitas kesehatan (puskesmas dan rumah sakit) dan kembali lagi ke rumah/komunitas.

Kota Ternate merupakan salah satu kota yang memiliki angka kasus HIV/AIDS terbanyak di Provinsi Maluku Utara. Beberapa program penanggulangan dan pencegahan masalah HIV/AIDS sudah dilaksanakan oleh instansi teknis seperti Dinas Kesehatan Kota Ternate dan fasilitas pelayanan pertama (Puskesmas), Rumah Sakit dan lembaga Komisi Penanggulangan AIDS (KPA) Kota Ternate dan Lembaga yang peduli terhadap maslah HIV/AIDS. Dengan adanya peningkatan kasus HIV/AIDS yang setiap tahunnya dan masih adanya stigma dan diskriminasi terhadap teman-teman ODHA, sehingga KPA kota Ternate membentuk suatu komunitas yang peduli terhadap teman-teman ODHA yaitu KDS/LKS Maku Dudara.

KDS/LKS Maku Dudara merupakan salah satu komunitas yang didalamnya terhimpun orangorang dari berbagai kelompok resiko tinggi dengan status HIV positif (ODHA). Pembentukan KDS/LKS Maku Dudara di Kota Ternate ini bertujuan memberikan dukungan secara psikologis kepada temanteman populasi kunci dan ODHA maupun keluarganya. Sehingga ODHA dan populasi kunci dapat menjalankan hidupnya sehari-hari tanpa adanya stigma dan diskriminasi sehingga ODHA dapat berdaya secara mandiri untuk meningkatkan kualitas hidup yang lebih baik yaitu dengan mandiri, lebih percaya diri, dan memiliki kepatuhan terahadap pengobatan ARV

\section{Metode Kerja}

Pemberdayaan masyarakat melalui KDS pada ODHA Kota Ternate, metode dilaksanakan dengan Observasi dan wawancara langsung dengan Kelompok Dukungan Sebaya/ LKS Makududara dengan Tahap Persiapan,Tahap Pengkajian, Tahap Perencanaan Alternatif Program Atau Kegiatan, Tahapan Pemformalisasi Rencana Aksi, Tahap Pelaksanaan (Implementasi) Program atau Kegiatan, Tahap Evaluasi. Lokasi adalah LKS Makududara KoTA Ternate Provinsi Maluku Utara tahun 2020.

\section{Hasil}

\subsection{Tahap Persiapan}

Pada kondisi ini KDS/LKS Maku Dudara telah memiliki tenaga atau staf yang dapat memberdayakan teman-teman ODHA melalui dampingan KDS/LKS Maku Dudara. Sebelum pelaksanaan kegiatan dimulai terlebih dahulu menyiapkan agenda dilapangan seperti berkoordinasi dengan petugas kesehatan (dokter IMS dan HIV AIDS, petugas farmasi maupun petugas konselor) agar 
nantinya kegiatan berjalan sesuai dengan kebutuhan masalah kesehatan teman-teman ODHA. KDS/LKS Maku Dudara yang saat ini berjalan masih menggunakan anggaran sendiri atau swadaya dari para pengurus. Sehingga setiap kegiatan yang dilakukan sebagian besar merupakan secara sukarelawan.

\subsection{Tahapan Pengkajian (Assesment)}

Setiap kegiatan yang dilaksanakan KDS/LKS Maku Dudara secara komunitas atau keputusan bersama di dalam KDS/LKS tersebut. Kegiatan yang dilakukan dilihat dari kebutuhan teman-teman ODHA akan masalah kesehatan yang dihadapi.

\subsection{Tahap Perencanaan Alternatif Program Atau Kegiatan}

Setiap pengurus KDS /LKS Maku Dudara memiliki kemampuan sebagai fasilitator dalam memberikan motivasi kepada sesama teman-teman ODHA bahwa mereka membutuhkan dukungan secara psikologis terhadap kondisi kesehatan saat ini (dengan status HIV). Tidak mudah setiap ODHA menerima status kesehatannya dengan status HIV positif. Sehingga secara perlahan dapat menghilangkan stigma dan diskriminasi terhadap ODHA dilingkungan keluarga maupun masyarakat setempat.

\subsection{Tahapan Pemformalisasi Rencana Aksi}

Program kegiatan KDS/LKS Maku Dudara disusun sesuai dengan rencana yang dijadwalkan sesuai dengan anggaran yang tersedia.

\subsection{Tahap Pelaksanaan (Implementasi) Program atau Kegiatan}

Keikutsertaan teman-teman ODHA terlibat di dalam pengurus KDS/LKS Maku Dudara diharapkan mampu menjalankan program kegiatan yang dapat memberi dukungan kepada temanteman sesama ODHA. Kerjasama antara pengurus KDS/LKS Maku Dudara bersama teman-teman ODHA dengan fasilitas pelayanan kesehatan selama ini berjalan dengan baik. Beberapa kegiatan yang sudah dilaksanakan oleh KDS/LKS Maku Dudara yaitu :

1. Pendampingan dan Penjangkauan Populasi Kunci dan ODHA

Untuk menurunkan angka kesakitan dan kematian akibat infeksi HIV. Kegiatan ini dilaksanakan jika kelompok populasi kunci atau kelompok resiko tinggi maupun ODHA memerlukan dukungan. Dukungan yang diberikan baik dalam bentuk dukungan psikosoial maupun dukungan finansial. Kegiatan pendampingan dan penjangkauan populassi kunci dan ODHA seperti :

a. Mendampingi populasi kunci berkunjung ke layanan kesehatan untuk melakukan tes IMS atau tes HIV.

b. Mendampingi ODHA untuk mengambil obat ARV dilayanan kesehatan.

c. Mendampingi populasi kunci maupun ODHA berkonsultasi dengan petugas kesehatan terkait masalah kesehatan yang dihadapinya.

d. Menjangkau populasi kunci untuk memberikan edukasi terkait IMS dan HIV AIDS serta mengajak untuk melakukan tes IMS dan tes HIV.

e. Menjangkau populasi kunci untuk mengetahui jumlah populasi kunci yang terdapat di Kota Ternate.

f. Menjangkau ODHA agar tetap patuh pada pengobatan ARV.

g. Melakukan tracking jika adad teman-teman ODHA yang mengalami putus berobat. Jika ditemukan maka di damping samapai ODHA tersebut menjalani pengobatan kembali.

2. Memfasilitasi Akses Layanan Kesehatan

Jika Populasi kunci atau kelompok resiko tinggi atau ODHA membutuhkan akses layanan kesehatan seperti :

a. Membantu ODHA untuk mengambil obatnya di layanan kesehatan jika ODHA tersebut masih malu berkunjung ke layanan kesehatan. Selain itu juga ada ODHA yang tidak memiliki biaya transportasi untuk ke layanan kesehatan.

b. Berkoordinasi dengan petugas kesehatan terkait dengan masalah kesehatan yang dihadapinya, sehingga ODHA tetap mendapatkan hak layanan kesehatan.

c. Berkoordinasi dengan petugas kesehatan di layanan terkait dengan masalah administrasi ODHA yang dirawat di layanan kesehatan. 


\section{Bincang Bincang Sehat (BBS)}

Kegiatan yang dilaksanakan setiap bulannya dengan tujuan membahas permasalahan kesehatan yang berkaitan dengan kondisi ODHA maupun populasi kunci atau kelompok resiko tinggi. Kegiatan BBS seperti :

a. Lintas Sektor, beberapa kegiatan yang dilakukan KDS/LKS Maku Dudara bekerjasama dengan beberapa instansi terkait seperti Dinas Kesehatan Provinsi maupun Kota, Dinas Sosial dan tenaga Kerja, Dinas Pendidikan dan Kebudayaan, Dinas Pariwisata, Palang Merah Indonesia maupun Balai Wasana Bahagia Kemensos Ternate. Kegiatannya seperti edukasi, sosialisasi atau penyuluhan maupun memberikan bantuan finansial kepada teman-teman ODHA dan populasi kunci. Adanya pemberian bantuan finansial sebagai bantuan stimulus kepada ODHA dalam membantu masalah perekonomian.

b. Pelibatan Perguruan Tinggi, dengan melibatkan perguruan tinggi dalam program rutin KDS/LKS Maku Dudara merupakan kegiatan pengabdian masyarakat oleh staf pengajar. Selama ini KDS/LKS Maku Dudara selau bekerjasama dengan Fakultas Ilmu Kesehatan UMMU, seperti memberikan penyuluhan tentang masalah kesehatan masyarakat.

4. Bakti Sosial

Kerjasama dengan beberapa lintas sektor jika populasi kunci atau kelompok resiko tinggi atau ODHA membutuhkan bantuan secara finansial. Selain itu juga adanya dukungan program yang diberikan oleh Balai Rehabilitasi Sosial ODHA Kementerian Sosial melalui KDS/LKS Maku Dudara untuk memberikan bantuan pada teman-teman ODHA mengalami kekurangan finansial.

5 Kunjungan Rumah ODHA

Tujuannya memberikan dukungan kepada ODHA terkait dengan status HIVnya agar tetap patuh terhadap pengobatan ARV selain itu juga memberi pemahaman kepada keluarga terkait dengan HIV AIDS sehingga tidak ada stigma dan diskriminasi dari pihak keluarga. Dimana kegiatan ini bertujuan keluarga bisa menjadi pengawas minum obat bagi ODHA dan selalu menjadi motivasi agar ODHA tetap lebih berdaya.

6 Hari AIDS Sedunia (HAS)

Kegiatan rutin yang dilaksanakan setiap tahunnya sebagai agenda memperingati Hari AIDS Sedunia. Sebagai moment untuk mengingatkan perjuangan para sahabat ODHA. Kegiatan ini bisayan dilakukan kerjasama dengan beberapa lintas sektor maupun organisasi kepemudaan dan masyarakat.

7 Monitoring dan Evaluasi

Pelaksanaan monitoring dan evaluasi ini sebatas berjalan pada KDS/LKS Maku Dudara, dikarenakan Kota Ternate belum memiliki KDS ODHA lainnya. Selain itu juga KDS/LKS Maku Dudara melakukan monitoring dan evaluasi kepada para ODHA yang mendapat bantuan stimulus dari Balai Wasana Bahagia Kemensos Ternate.

\subsection{Tahap Evaluasi}

Evaluasi dilakukan untuk mengetahui sejauh mana berjalan suatu program. KDS/LKS Maku Dudara setiap tiga bulan sekali selalu melakukan evaluasi pelaksanaan program kegiatan dengan melibatkan semua pengurus. Diharapkan dengan adanya tahap evaluasi ini setiap pengurus dapat memberikan masukan demi keberlangsungan komunitas dan dapat diubah jika terdapat kesalahan.

\section{PENUTUP}

KDS/LKS Maku Dudara mempunyai program rutin yaitu lakukan pendampingan dan penjangkauan pada ODHA dan populasi kunci serta memberikan edukasi bagi ODHA dan keluarganya dan melakukan kegiatan social lainnya. Staf KDS/LKS Maku Dudara mampu memberdayakan temanteman ODHA melalui dampingannya, walaupun berjalan secara sukarela. Hal ini sesuai dengan visi misi dari KDS/LKS Maku Dudara bahwa memberikan dukungan psikologis kepada ODHA yang membutuhkan. Adanya keterbukaan status HIV pada beberapa instansi terkait sehingga bisa dilakukannya kerjasama dengan KDS/LKS Maku Dudara untuk mendapat dukungan baik secara finansial maupun program penanggulangan masalah HIV/AIDS di Kota Ternate 


\section{DAFTAR PUSTAKA}

Berger, M. B., Sullivan, K. A., Parnell, H. E., Keller, J., Pollard, A., Cox, M. E., Clymore, J. M., \& Quinlivan, E. B. (2016). Barriers and Facilitators to Retaining and Reengaging HIV Clients in Care: A Case Study of North Carolina. Journal of the International Association of Providers of AIDS Care, 15(6), 486-493. https://doi.org/10.1177/2325957415616491.

Brégigeon-Ronot, S., Cheret, A., Cabié, A., Prazuck, T., Volny-Anne, A., Ali, S., Bottomley, C., Finkielsztejn, L., Philippe, C., \& Parienti, J. J. (2017). Evaluating patient preference and satisfaction for human immunodeficiency virus therapy in France. Patient Preference and Adherence, 11, 1159-1169. https://doi.org/10.2147/PPA.S130276.

Djauzi, S. 2010. Masalah dan Tatalaksana HIV di Indonesia. Interna Publishing. Jakarta.

Carroll, L.J. 2007. Sexuality Now : Embracing Diversity edisi 2. Belmont: Thomson Journal Learning IncUSA.

Gay, Waria dan Lelaki Seks Lelaki (GWL) Muda, 2016. Buku Kesehatan dan Hak Seksual serta Reproduksi GWL Muda. KPAN \& UNAIDS, Jakarta. www.gwl-ina.or.id/wpcontent/uploads/2016/03/BAB5-HIV-AIDS.pdf.

Kioko, M. T., \& Pertet, A. M. (2017). Factors contributing to antiretroviral drug adherence among adults living with HIV or AIDS in a Kenyan rural community. African Journal of Primary Health Care and Family Medicine, 9(1), 1-7. https://doi.org/10.4102/phcfm.v9i1.1343.

Mandal, K.B.,dkk. 2008. Lecture Notes on Infectious Diseases (6th ed.). Journal Manchester: Blackwell Publishing Ltd.

Mukumbang, F. C., Mwale, J. C., \& Van Wyk, B. (2017). Conceptualising the Factors Affecting Retention in Care of Patients on Antiretroviral Treatment in Kabwe District, Zambia, Using the Ecological Framework. AIDS Research and Treatment, 2017. https://doi.org/10.1155/2017/7356362.

Mulqueeny, D. M., \& Taylor, M. (2017). Patients' recommendations for a patient-centred public antiretroviral therapy programme in eThekwini, KwaZulu-Natal. Southern African Journal of HIV Medicine, 18(1), 1-7. https://doi.org/10.4102/sajhivmed.v18i1.677.

Nasronudin. 2007. HIV \& AIDS Pendekatan Biologi Molekuler, Klinis dan Sosial. Airlangga University Press. Surabaya.

Noviana Nana. 2016. Konsep HIV/AIDS Seksualitas \& Kesehatan Reproduksi. CV. Ternas Info Media. Jakarta.

Pariaribo, K. (2015). Beberapa Faktor Risiko Yang Mempengaruhi Kepatuhan Terapi Antiretroviral (Arv) Pada Pasien Hiv/Aids (Studi Kasus Di Rsud Abepura). 1-75.

Seyoum, D., Degryse, J. M., Kifle, Y. G., Taye, A., Tadesse, M., Birlie, B., Banbeta, A., Rosas-Aguirre, A., Duchateau, L., \& Speybroeck, N. (2017). Risk factors for mortality among adult HIV/AIDS patients following antiretroviral therapy in southwestern ethiopia: An assessment through survival models. International Journal of Environmental Research and Public Health, 14(3), 1-12. https://doi.org/10.3390/ijerph14030296.

Stien, Gerald J. 2013. AIDS Update 2014. New York : The McGraw-Hill Companie inc.

Stigma, T., Di, M., Watumea, D., Pandelaki, I. D., \& Hamel, R. S. (2017). Pengaruh Penyuluhan Kesehatan 
Tentang Hiv-Aids Terhadap Stigma Masyarakat Di Desa Watumea Kecamatan Eris Kabupaten Minahasa. Jurnal Keperawatan, 5(2), 1-5.

WHO. (n.d.).HIV/AIDS @ www.who.int. https://www.who.int/gho/hiv/en/

WHO, 2017, Global Health Observation (GHO) data HIV/AIDS dariwww.who.int/gho/hiv/en

Widoyono. 2011. Penyakit Tropis: Epidemiologi, Penularan, Pencegahan \& Pemberantasannya Edisi 2. Erlangga. Jakarta.

Yehenew Getachew et all 2017, Risk Factors For Mortality among adult HIV/AIDS Patients Following Antiretroviral Therapy in Southwestern Ethiopia : An Assessment Though Survival Model, International Journal of Environmental Research and Public Health pada ww.proquest.com 